\title{
LUTEAL REGRESSION INDUCED BY ARACHIDONIC ACID IN THE PSEUDOPREGNANT RABBIT
}

\author{
L. H. HOFFMAN \\ Department of Anatomy, Vanderbilt University School of Medicine, \\ Nashville, Tennessee 37232, U.S.A.
}

(Received 8th June 1973)

Administration of prostaglandin $\mathrm{F}_{2 \alpha}\left(\mathrm{PGF}_{2 \alpha}\right)$ to pseudopregnant rabbits results in a rapid decline in luteal weight and progesterone secretion (Scott \& Rennie, 1970; Gutknecht, Duncan \& Wyngarden, 1971). There is evidence that PGF ${ }_{2 \alpha}$ may be the 'uterine luteolysin' in other species, in particular the sheep, guineapig and hamster (see Pharriss, Tillson \& Erickson, 1972). Indomethacin, a potent inhibitor of prostaglandin synthesis, has been shown to prolong the functional lifespan of CL in the pseudopregnant rabbit (O'Grady, Caldwell, Auletta \& Speroff, 1972). The fact that this prolongation of luteal life is similar to that produced by hysterectomy led O'Grady and co-workers to suggest that $\mathrm{PGF}_{2 \alpha}$ may be the uterine luteolysin in the rabbit.

As arachidonic acid (5,8,11,14-eicosatetraenoic acid) is a normal precursor of $\mathrm{PGF}_{2 \alpha}$ and $\mathrm{PGE}_{2 \alpha}$ (Bergström, Carlson \& Weeks, 1968), it might be expected to produce luteolytic effects in mammals. The purpose of this study was to determine the effect of archidonic acid on luteal maintenance in pseudopregnant rabbits and to determine whether or not the uterus is essential for the mediation of such effects.

Forty New Zealand white rabbits, weighing 3 to $4 \mathrm{~kg}$ each, were used for this study. They were housed in isolated cages for at least 15 days before being injected intravenously with 50 i.u. HCG (Antuitrin-S, Parke-Davis) for the induction of pseudopregnancy. The day of injection was designated Day 0 of pseudopregnancy.

Arachidonic acid (Sigma, Grade II, 90+\%) was dissolved in propylene glycol $(25 \mathrm{mg} / \mathrm{ml})$ and injected intraperitoneally once a day on Days 9 to 12 of pseudopregnancy. The 20-carbon saturated fatty acid, arachidic acid (neicosanoic acid, Sigma), was also injected intraperitoneally on the same days. This fatty acid required warming to $45^{\circ} \mathrm{C}$ to be put into solution and was injected using a pre-warmed hypodermic syringe. Indomethacin (Indocin, Merck) was given subcutaneously in sesame oil $(25 \mathrm{mg} / \mathrm{ml})$ at a dose level of $8 \mathrm{mg} / \mathrm{kg}$ body weight twice daily on Days 9 to 12 . This was the same dose level as that employed by O'Grady et al. (1972) to suppress luteolysis in rabbits.

The rabbits were allocated to nine groups of four and treated as follows: (1) intact pseudopregnant, no treatment; (2) intact pseudopregnant, $1 \mathrm{ml}$ propylene glycol/day; (3) intact pseudopregnant, $12 \mathrm{mg}$ arachidonic acid/day; (4) intact pseudopregnant, $25 \mathrm{mg}$ arachidonic acid/day; (5) intact pseudopregnant, 
$25 \mathrm{mg}$ arachidic acid/day; (6) intact pseudopregnant, $25 \mathrm{mg}$ arachidonic acid/day and $8 \mathrm{mg} / \mathrm{kg}$ indomethacin twice daily; (7) intact pseudopregnant, $8 \mathrm{mg} / \mathrm{kg}$ indomethacin twice daily; (8) hysterectomized bilaterally on Day 7 of pseudopregnancy, $1 \mathrm{ml}$ proplyene glycol/day; (9) hysterectomized on Day 7 and given $25 \mathrm{mg}$ arachidonic acid/day. All injections were administered on Days 9 to 12 of pseudopregnancy and the animals were killed on Day 13. The ovaries were removed, weighed and the CL dissected free. These were weighed to the nearest $0.1 \mathrm{mg}$ and preserved in Bouin's solution for subsequent histological processing. Sections of CL embedded in paraffin wax were stained with haematoxylin and eosin. Another group of four females (Group 10) was given local ovarian injections of archidonic acid. On Day 9 of pseudopregnancy, the ovaries were exposed through a mid-ventral incision and $12 \mathrm{mg}$ of arachidonic acid in $0.15 \mathrm{ml}$ propylene glycol were injected at three or four sites beneath the

Table 1. The effect of arachidonic acid on the luteal weight of rabbits

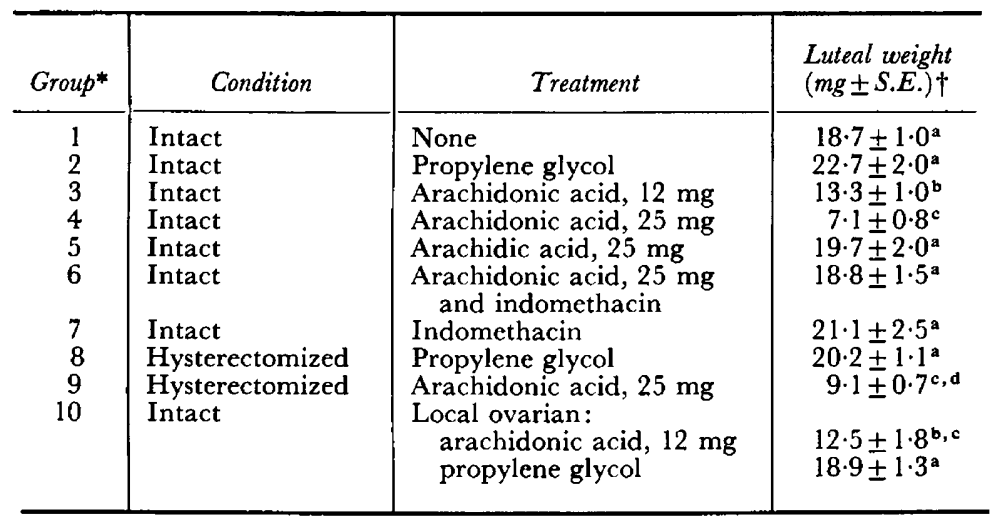

* Four females/group.

$\dagger$ Means with different superscripts are significantly $(P<0 \cdot 05)$ different.

tunica albuginea of one ovary. In each female, the contralateral ovary was injected with a similar volume of propylene glycol. These females were killed on Day 13 and the same procedures for assay of luteal maintenance were followed as those outlined above. Luteal weights of the different groups were compared for significant differences at the 5\% level using Duncan's multiple-range test (Duncan, 1957).

The results, based on luteal weight (Table 1), show that intraperitoneal injection of arachidonic acid resulted in rapid luteal regression. Although $12 \mathrm{mg}$ arachidonic acid/day (Group 3) reduced luteal weights significantly, $25 \mathrm{mg} /$ day was a more effective luteolytic dose level. A similar amount of the 20-carbon saturated analogue (Group 5), arachidic acid, had no effect on luteal maintenance. The administration of indomethacin (Group 7) had no effect on luteal size by Day 13. Indomethacin did block the luteolytic effect of arachidonic acid, however, when both were given simultaneously (Group 6). This suggests that the effect of arachidonic acid on the rabbit $\mathrm{CL}$ is due to its conversion into a prostaglandin. Arachidonic acid ( $25 \mathrm{mg} /$ day) was just as effective in hyster- 
PL. \TE I

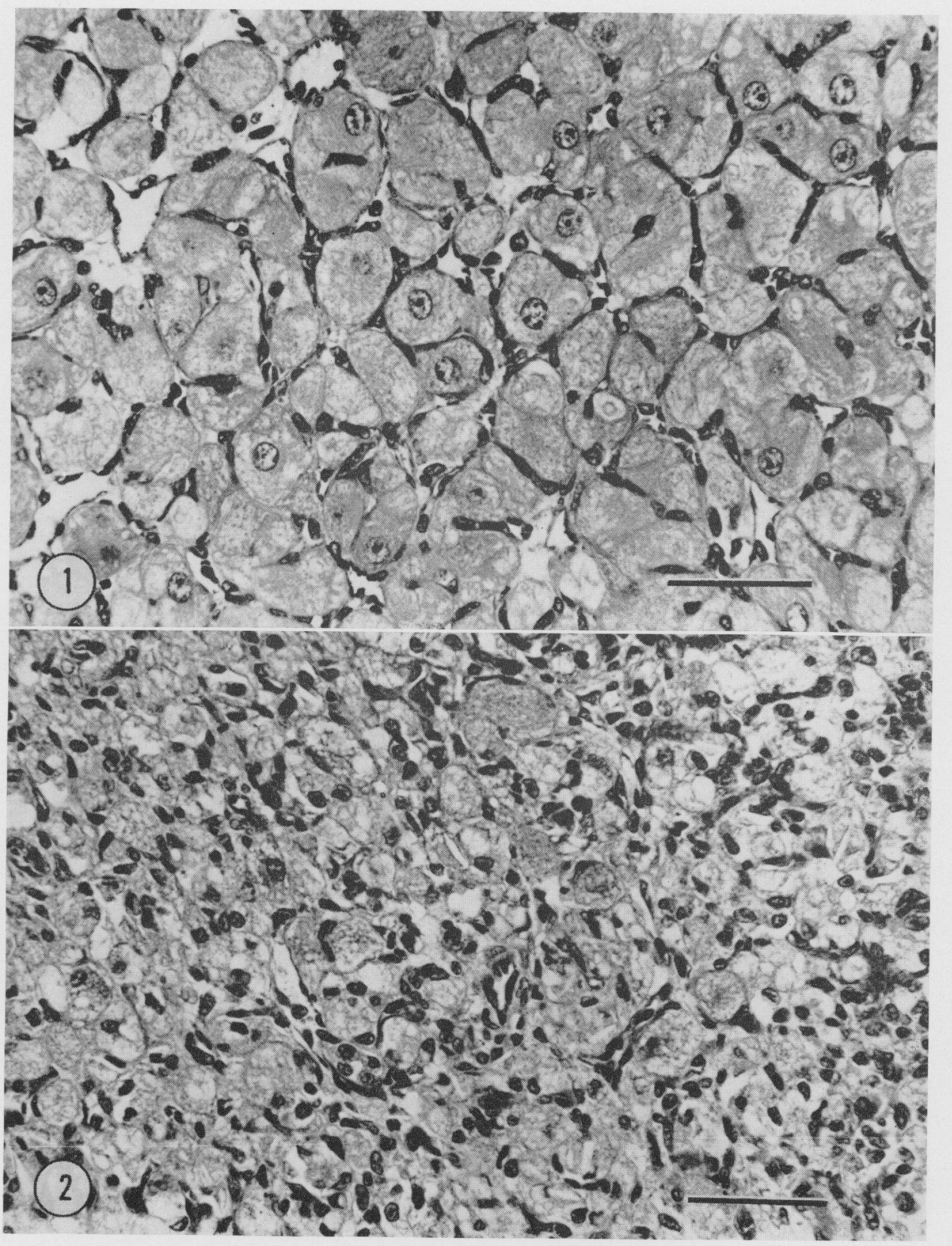

FIG. 1. Corpus luteum from a control doe (Group 2) recciving propylene glycol. Day 13 of pseudopregnancy. Scale $=50 \mu \mathrm{m}$.

FIs. 2. Corpus luteum from a doe which received $25 \mathrm{mg}$ arachidonic acid on Days 9 to 12 (Group 4). The luteal tissue has regressed markedly demonstrating shrinkage of colls. nuclear condensation, cytoplasmic vacuolation and an infiltration of connective tissue elements. Day 13 of pseudopregnancy. Scale $=50 \mu \mathrm{m}$. 
ectomized females (Group 9) as in intact females (Group 4). Thus, the uterus is apparently not required for conversion of arachidonic acid to prostaglandin. This conclusion is supported by the results of the local ovarian injections. A single ovarian injection of $12 \mathrm{mg}$ arachidonic acid (Group 10, arachidonic) lowered luteal weights significantly while the contralateral ovary, which received the glycol injection vehicle, contained CL of normal size. The luteal weights following local injection of $12 \mathrm{mg}$ arachidonic acid were not significantly different from the luteal weights of females receiving four daily doses of the same substance intraperitoneally at the 12-mg level (Group 3). Propylene glycol had no effect on luteal weight whether injected intraperitoneally (Group 2) or into the ovary (Group 10, glycol).

These results, based on luteal weights and demonstrating arachidonateinduced luteolysis, were supported by histological examination of the CL. Females (intact or hysterectomized) given propylene glycol (Pl. 1, Fig. 1), arachidic acid or indomethacin showed no morphological signs of luteal regression on Day 13. Corpora lutea from females (intact or hysterectomized) which received arachidonic acid intraperitoneally showed advanced luteal regression on Day 13 (Pl. 1, Fig. 2). Local ovarian injection or arachidonic acid produced large areas of extravasation of red cells and local accumulation of leucocytes in the ovarian tissue, while the contralateral ovaries injected with glycol were quite normal in all respects. As luteal regression was similar, both morphologically and gravimetrically, following local ovarian or intraperitoneal administration of arachidonic acid (12 $\mathrm{mg} \mathrm{level}$ ), it seems unlikely that the leucotactic property of arachidonic acid was responsible for luteal regression following local injection of this fatty acid.

The results of this study demonstrate that the precursor of $\mathrm{PGF}_{2 \alpha}$ (and $\mathrm{PGE}_{2}$ ), arachidonic acid, induces premature luteolysis in pseudopregnant rabbits when administered either intraperitoneally or into the ovary. The fact that indomethacin, a known inhibitor of prostaglandin biosynthesis (Vane, 1971), blocks arachidonate-induced luteolysis suggests that prostaglandins (probably $\mathrm{PGF}_{2 \alpha}$ ) are involved in this premature luteal regression and may be associated with the normal decline in luteal size and function late in pseudopregnancy. These observations do not necessarily support the notion (O'Grady et al., 1972) that $\mathrm{PGF}_{2 \alpha}$ is the uterine luteolysin in rabbits, however, as the presence of uterine tissue is not required for the mediation of the luteolytic effect of arachidonic acid. Although the non-pregnant uterus of the rabbit is demonstrably luteolytic (Asdell \& Hammond, 1933), no local (unilateral) luteolytic effect of a uterine horn on the adjacent ovary has been demonstrated in the rabbit (Hunter \& Casida, 1967). In the sheep (McCracken, Baird \& Goding, 1971), prostaglandins of uterine origin reach the adjacent ovary in high concentrations by virtue of intimate utero-ovarian vascular associations. No such relationships between uterine and ovarian vessels have been demonstrated in the rabbit. Thus, while it seems likely that a prostaglandin may be the physiological luteolysin at the ovarian level, conclusive evidence that prostaglandins are the endometrial luteolysin in rabbits is lacking. Although it is known that increases in $\mathrm{PGF}_{2 \alpha}$ levels in bovine utero-ovarian venous blood coincide with declining progesterone levels (Nancarrow \& co-authors 1973), 
Hansel, Concannon \& Lukaszewska (1973) have obtained a fatty acid-containing fraction of bovine endometrium which had greater luteolytic activity than the prostaglandin-containing fraction of the same tissue. They suggest that the bovine endometrium may exert its local luteolytic effect by providing the CL with one or more precursors which are converted into prostaglandins or other luteolysins in situ by the luteal tissue. In view of the results of the present study, this possibility seems worthy of further investigation in the rabbit.

The author wishes to thank Mrs Virginia Long for technical assistance. This study was supported by Grant HD 05942, National Institutes of Health.

\section{REFERENCES}

Asdeld, S. A. \& Hammond, J. (1933) Effects of prolonging the life of the corpus luteum in the rabbit by hysterectomy. Am. J. Physiol. 103, 600.

Bergström, S., Garlson, L. A. \& Weeks, J. R. (1968) The prostaglandins: a family of biologically active lipids. Pharmac. Rev. 20, 1.

Duncan, D. B. (1957) Multiple range tests for correlated and heteroscedastic means. Biometrics, 13, 164.

Gutknecht, G. S., Duncan, G. W. \& Wyngarden, L. J. (1971) Inhibition of prostaglandin $F_{2 \alpha}$ ro LH-induced luteolysis by $17 \beta$-estradiol. Biol. Reprod. 5, 87, Abstr.

Hansel, W., Concannon, P. W. \& Lukaszewska, J. H. (1973) Corpora lutea of the large domestic animals. Biol. Reprod. 8, 222.

Hunter, G. L. \& Casida, L. E. (1967) Absence of local effects of the rabbit uterus on weight of corpus luteum. 7. Reprod. Fert. 13, 179.

McCracken, J. A., Baird, D. T. \& Goding, J. R. (1971) Factors affecting the secretion of steroids from the transplanted ovary in the sheep. Recent Prog. Horm. Res. 27, 537.

Nancarrow, C. D., Buckmaster, J., Chamley, W., Cox, R. I., Cumming, I. A., Cummins, L., Drinan J. P., Finlay, J. K., Goding, J. R., Restall, B. J., Schneider, W. \& Thorburn, G. D. (1973) Hormonal changes around oestrus in the cow. J. Reprod. Fert. 32, 320, Abstr.

O'Grady, J. P., Caldwell, B. V., Auletta, F. J. \& Speroff, J. (1972) The effects of an inhibitor of prostaglandin synthesis (indomethacin) on ovulation, pregnancy, and pseudopregnancy in the rabbit. Prostaglandins, 1, 97.

Pharriss, B. B., Tillson, S. A. \& Erickson, R. R. (1972) Prostaglandins in luteal function. Recent Prog. Horm. Res, 28, 51.

Scott, R. S. \& Rennie, P. I. G. (1970) Factors controlling the life-span of the corpora lutea in the pseudopregnant rabbit. F. Reprod. Fert. 23, 415.

VANE, J. R. (1971) Inhibition of prostaglandin synthesis as a mechanism of action for aspirin-like drugs. Nature, New Biology, 231, 232. 